\title{
5
}

\section{Bush Medicine Knowledge and Use among Young Kriol Speakers in Ngukurr}

\author{
Greg Dickson
}

In 2013, in a Ngukurr backyard, I was preparing to interview a young mother about her knowledge and use of bush medicine. It was a familiar remote community scene-outdoor social space populated by ebbing and flowing tides of various relatives. Present at the time was me, the young Kriol-speaking mum who had agreed to be interviewed, some kids, the parents of the interviewee and a visiting elder of some stature in the community. Each generation had distinctive upbringings: the visiting elder had been born in the bush and the parents of the interviewee were mission raised. Their daughter - the target of my interview-was old enough to have spent considerable time on local outstations when they were funded, while the children were a southern Arnhem Land version of 'urbanised' in Ngukurr. We all spoke in Kriol, as is the norm in Ngukurr, despite the older people present having knowledge of traditional languages. I was explaining the premise of my little study-in Kriol. Hearing that I was investigating what young people know about bush medicine, the visiting elder declared, with some disdain, 'they don't know nothing. This chapter focuses on the issue of language retention among youth in this community. The research was conducted at the same time as the Ngukurr research that generated the other chapters in this book and so is situated within an exchange of ideas about health and wellbeing, particularly in regard to traditional knowledge and bush medicine. 
Stated beliefs that younger generations are not retaining cultural knowledge and practices of their forebears are common. They can be heard coming from elders, from non-local/non-Indigenous commentators and even among young people themselves. These perceptions are unsurprising given the sharp shifts in lifestyles that remote Aboriginal societies have experienced in so few generations. Language shift-in which younger generations speak a different language from preceding generationsis a salient phenomenon, inescapably noticeable given the obvious primacy of verbal communication in daily life. Loss of language (or, more accurately, language shift) becomes an easy hook on which to hang feelings of loss when a group or society is stressed and ways of life are threatened. In its crudest form, this manifests as the sentiment: 'got no language, got no culture'.

There is certainly good anecdotal evidence to affirm ideas of disappearing cultural knowledge and practices. In Ngukurr, no one has made or paddled a dugout canoe for decades and there are now two generations who have never seen or hunted goanna. ${ }^{1}$ But, as a blanket statement, beliefs that young people are not retaining cultural knowledge are rarely investigated.

\section{Is the Practice of Bush Medicine at Ngukurr Diminishing?}

The loss of knowledge and use of traditional or 'bush' medicine is typically deemed to exemplify the loss of knowledge and diminished cultural practices more generally among Kriol-speaking adults in Ngukurr and elsewhere. Take, for example, an early claim (in antiquated language) that, 'as civilization spreads into primitive areas, the first aspect of primitive culture to be lost is knowledge of the use of plants as medicine' (Farnsworth 1966, 229). When linguist Jeffrey Heath (1980, 445) documented Nunggubuyu (traditionally spoken to the immediate north-east of Ngukurr) in the 1970s, he claimed that 'bush medicine is ... practiced to a limited extent, chiefly by older people'. More recently, a study into health beliefs in Ngukurr supported this, finding 'little evidence that people were currently using bush medicines on a regular basis' (Senior 2003, 115). Another manifestation of ideas that bush medicine knowledge and usage

1 Editor's note: There was considerable excitement in Ngukurr, when, in 2018, goannas were seen (and hunted) near the community. 
is endangered knowledge are compensatory efforts to document ethnobotanical knowledge held by senior custodians (e.g. Levitt 1981; Scarlett, White and Reid 1982; Latz 1995; Winydjorrodj et al. 2005; Roberts et al. 2011; Hector et al. 2012; Bordulk et al. 2012).

Upon commencing my research, I too adhered to the ideas mentioned above. I assumed that an investigation into bush medicine would exemplify loss of cultural practices, rather than maintenance. The bush medicine sub-study was to contrast with an exploration of kinship-a domain believed to more robustly exhibit cultural continuities across language shift. As readers will see, beliefs about diminishing bush medicine practices turned out to be somewhat of a misconception.

\section{Working with Old People and the Ubiquity of Bush Medicine}

My involvement with Ngukurr goes back to 2004 when I was employed by Diwurruwurru-Jaru Aboriginal Corporation (aka Katherine Regional Aboriginal Language Centre) as the Ngukurr-based community linguist, a position I held for three years before moving to Katherine. Since then, I have continued to work with senior community members who are speakers of various endangered traditional languages and supported their endeavours to prolong the longevity of their critically endangered languages. Given the intrinsic link between land and language (Merlan 1981), a fundamental aspect to language revitalisation and documentation work is travel to various sites. Sometimes, the travel reconnects elders with a particular geographic landmark (e.g. sacred site) important to their language group. Other times, it reconnects them with speakers or stakeholders of the given language living in another location. Sometimes, our trips would just be to spend time fishing, hunting or procuring materials from the bush (food, medicine or stuff needed to make artefacts)— travel combining leisure, economic and cultural maintenance purposes.

Across dozens of journeys of these types, the importance of bush medicine to senior people in Ngukurr became obvious. Even when remaining in Ngukurr, spending time with older people regularly includes a request, longing for or appreciation of bush medicine. When journeying out of Ngukurr, more often than not, I'd be told to stop (if I was driving) and, typically, someone would spring from the vehicle, with or without 
explanation, and return a few minutes later with several branches of a common medicine type. One elder in particular, Betty Roberts (to whom I dedicated my $\mathrm{PhD}$ thesis for her decades-long commitment to language work), would usually be able to produce some form of bush medicine from her bag-whether it was some recently nabbed leaves or a decoction of some variety.

Further evidence of senior people maintaining bush medicine traditions came from community projects. In the 1980s, the local Nganiyurlma Media Association (1990) prioritised bush medicine and made it the topic of a 72-minute edited video. ${ }^{2}$ In the 1990s, Marra elders working with Diwurruwurru-Jaru Aboriginal Corporation produced a three-volume in-house publication on Marra plants and Their Uses (Huddleston et al. n.d.-a, n.d.-b, n.d.-c) and, during my time as the corporation's Ngukurrbased linguist, Betty and her sister assisted in developing more bush medicine materials. In 2007, they composed a series of short monolingual texts in Marra describing 14 taxa, providing a unique example of written documentation of bush medicine knowledge composed by Marra speakers themselves.

My observations, coupled with what McClatchey (2012) calls 'secondary or documentary evidence' (e.g. written documentation, new and existing audio recordings, and photographs), demonstrates that, for older generations who grew up speaking and hearing the traditional languages of Ngukurr, bush medicine is an important part of expressed and practiced cultural life.

\section{Young People and Bush Medicine: Some Observations}

But what of younger people in Ngukurr, young adults who-along with their parents, peers and children-all speak Kriol and are rarely immersed in traditional languages? In the early stages of my doctoral fieldwork in 2010, I was at Yawurrwarda billabong, only a few kilometres from Ngukurr, with a senior man of Marra heritage aged in his 60s and three women aged in their 20 s who all call him 'father'. One of the women had

2 This video, Bush Medicine from Ngukurr, features prominent elders including Ginger Riley, Willie Gudabi, Sambo Barra Barra and Sam Thompson, describing and demonstrating 10 medicinal taxa, bookended by commentary from senior Aboriginal health worker Alex Thompson. 
brought two of her kids, aged about five and eight at the time. We were making recordings in Kriol involving all except the young mum, who, having moved away a short distance to leave us in (relative) peace, took up the opportunity for a quick fish in the billabong while minding her children. At the time, her son (aged five) had some painful boils or skin sores. While we were doing our 'language work', the young mum took it upon herself to quietly and matter-of-factly cut bark from a nearby ngalangga (Eucalyptus camaldulensis) tree. Though she had taken her son to the local medical clinic for treatment, she had also self-prescribed treating her son's condition with ngalangga and had sufficient knowledge to independently acquire and prepare the medicine herself. This was a sign that not only are young people using bush medicine but also that it could fly under the radar, unnoticed by outsiders.

If this young mother's competent prescription and procurement was surprising, stated beliefs in the efficacy and value of bush medicine were not. Senior's $(2001,8)$ finding that 'a clear preference was stated for the use of bush medicines' certainly applied to the young adults I interviewed. Two women in their 30s demonstrate this quite emphatically, although note also that one also values Western medicine to a degree: ${ }^{3}$

(1)

GD: wani yu laigi mo, munanga medisin o bush medisin?

what do you like more, Western medicine or bush medicine?

GD: [o bouth?

or both?

EN: [bush medisin

bush medicine

PD: bush medisin=

bush medicine

$\mathrm{EN}: \quad=$ bush medisin

=bush medicine

EN: det munanga medisin, im meigi yu wik

Western medicine, it makes you weak

3 Some symbols and conventions used in conversation analysis are utilised in interview transcripts in this chapter. Square brackets indicates the talk overlaps with the neighbouring line of square bracketed speech. The = sign indicates the talk is latched on to prior talk with no gap or lapse in between. 
PD: sam ... [lilbit rait, help you

some...(is) kind of okay, (it) helps you

EN: [meigi yu slip, en, makes you sleep, and

PD: ome I don't like, like, takin' it too much ... all different ones

Accompanying this rhetoric, the women quoted above demonstrated declarative knowledge of numerous (around 10) bush medicine taxa. Others I interviewed did not. Yet, despite two young men in their 20s declaring that 'mela nomo sabi bush medisin' (we don't know bush medicine), they maintained an aversion to Western medicine despite the self-identified knowledge gap, expressing a reliance on elders for bush medicine treatments:

GD: bat wani yunbala regen, yunbala regen ... laik, yu jas tras la munanga medisin na?

but what do you two think, do you two think ... like ... do you trust only Western medicine now?

KM: $n a=$

no

DR: =ai nomo dringgi, [ai nomo] oldei dringgim munanga medisin wen mi sik=

I don't take, I don't take Western medicine when I'm sick

$\mathrm{KM}: \quad$ not $m e]$

$\mathrm{KM}: \quad=$ not me, ai nomo gunot me, I don't go-

DR: me-mela nomo, mela nomo gu na, na, na, na hospel o na klinik ba dringgim medisin laik-... yuno, ba, ba peinkila, mela nomo yusu we-, we don't, we don't go to, to, to, to the hospital or to the clinic to take medicine, like- ... you know, for, for painkillers, we don't use it

GD: ngi?

don't you?

DR: bikos mela nomo sabi wani (xx xx) them staf, yuno because we don't know what (is in) that stuff, you know 
GD: so if you sikwan, mo beda yu dringgim= so if you're sick, it's preferable that you drink=

DR: =bush medisin= =bush medicine $=$

GD: $n g i ?=$ is it?=

$\mathrm{KM}: \quad=m m=$

DR: =so im natural, straight from, yuno, [plent en det=so it is natural, straight from, you know, plants and that-

KM: $\quad$ so main klinik la det olgamen $n a^{4}$ so my clinic is that old lady

GD: yuwai yeah

DR: ola olpipulmo' bala alabat didei! The poor elders, my heart goes out to them these days. ${ }^{5}$

During the interviews, young people typically shared stories of applying certain medicines and gave testimonials supporting their efficacy. One 31-year-old man described treating his son's sores with bush medicine during a visit to another community. Speaking of the results of the treatment, he said:

Neksdei, alibala na, imin jis klin na. En detmo la Beswick bin gedimbat shok.

Then next day, early, it was really clear (i.e. his skin). And those guys at Beswick were really surprised.

Another interviewee, a 33-year-old female, spoke of using the bark of Buchanania obovata to treat toothache, saying emphatically: 'Im wek. Streitawei im wek' (It works. It works immediately).

$4 \mathrm{KM}$ is referring to Betty Roberts, mentioned above, who had been referred to previously in the interview as an expert in bush medicine.

5 Here bala (a shortened form of bobala from 'poor fellow') is an exclamation of bittersweet sorrow. It is not necessarily a negative feeling as indicated by the etymon 'poor fellow' but rather indicates a feeling of fondness, longing, pity, nostalgia or a feeling of missing somebody or something, hence the translation: 'heart goes out to'. 


\section{Young People and Bush Medicine}

In May 2013, I interviewed 14 adults at Ngukurr, utilising methods described by Hoffman and Gallagher (2007). The participants were recruited through personal contacts and through promoting the study on social media. The participants were an equal gender split and aged between 22 and 35 (mean: 29 years). The group was diverse across various social demographics including education, employment status and occupations types. Most (but not all) had children and all had lived in the region for most of their lives. In terms of language abilities, they all spoke Kriol as a first language and had competencies in English varying from fair to excellent. Knowledge of traditional languages was generally low: five reported no knowledge, seven reported little knowledge, and two reported being fluent speakers (one of Wägilak and one of Anindilyakwa) due to heritage and time spent in other locations where those languages are in regular use.

I am a fluent speaker and accredited Kriol-English interpreter. I conducted the interviews in Kriol at various locations in Ngukurr. The interviews lasted 25-30 minutes and were structured accordingly:

1. personal information

2. free-listing exercise (i.e. list as many types of bush medicine as you can)

3. recent use: describe the most recent occasion you used bush medicine (time, ailment, treatment, procurement, result, etc.)

4. checklist exercise: a reference list of 38 bush medicine names in Kriol and Indigenous languages, checking for recognition and declarative knowledge, adding to taxa listed in Part 2

5. preference exercise: list 'top 5' bush medicines

6. free-listing exercise on lizard taxa (data on an additional ethnobiological domain for comparability).

\section{Results}

The free-listing exercise asked participants to list as many types of bush medicine as they could. Variation in identification methods were accommodated: participants were free to identify taxa by an Indigenousderived name, a Kriol or English-derived name, or by description or pointing/indicating. 
The number of taxa the 14 participants could list ranged from between 3 and 9 (mean: 6). There was some gender differentiation, with the seven male participants' range being 3 to 7 (mean: 4.9) and female participants ranging from 5 to 9 (mean: 7.1).

A further consideration was the sum total of taxa enumerated across the group. Across the 14 participants, 21 taxa were listed. Gender differentiation was negligible when examining the results this way, with men listing 15 taxa in total and women listing 16. However, age was a factor, with the seven participants aged under 30 (aged 22-29) describing a total of 12 taxa and the seven older participants aged 30-35 collectively describing 20 taxa. $^{6}$

As an indication of the figures that might be expected from senior people, my research on evidence documented from Ngukurr elders shows collective knowledge of at least 26 bush medicine taxa. A recent study of knowledge held by Mangarrayi and Yangman elders (in the neighbouring upper Roper River region) listed 37 plant species as having reported medicinal properties (Roberts et al. 2011).

Following the free-listing task, I referred to a checklist of 38 attested local bush medicine names (a mix of Indigenous-language derived and Englishderived names) and read them to participants, allowing them to recall further knowledge. All but one participant increased the number of bush medicine taxa they reported knowledge of. Following the checklist, the average number of taxa known to each participant increased from 6 to 8.6 and the range shifted from 3 to 9 to 4 to 13. Male participants had more of their memory jogged than the women, with the average number of taxa known to men shifting from 4.9 after only the free-listing task to 7.7 after the checklist. For women, the mean increased from 7.1 to 9.5. Age differentiation became more prominent following the checklist, with the under 30s' mean increasing by 1.3 to 6.3 ; however, the cohort aged between 30 and 35 recalled an additional 3.9 taxa on average, increasing the mean to 10.9 .

6 These quantitative data need to be interpreted with caution due to the very small sample size. It should be noted, though, that age was not a clear predictor: the youngest person interviewed (22) listed more than the average at 8 taxa while one of the two oldest (35) listed a less-than-average 5 taxa. 
INDIGENOUS AUSTRALIAN YOUTH FUTURES

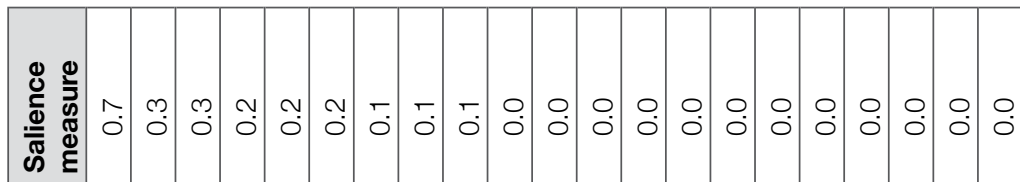

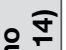

$$
\begin{aligned}
& \text { "3 }
\end{aligned}
$$

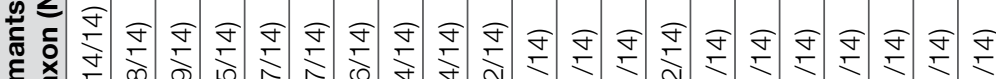

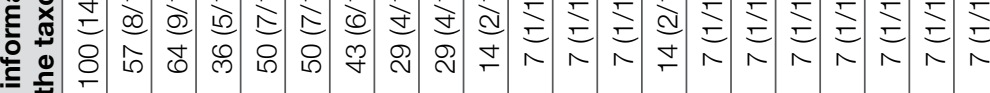

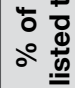

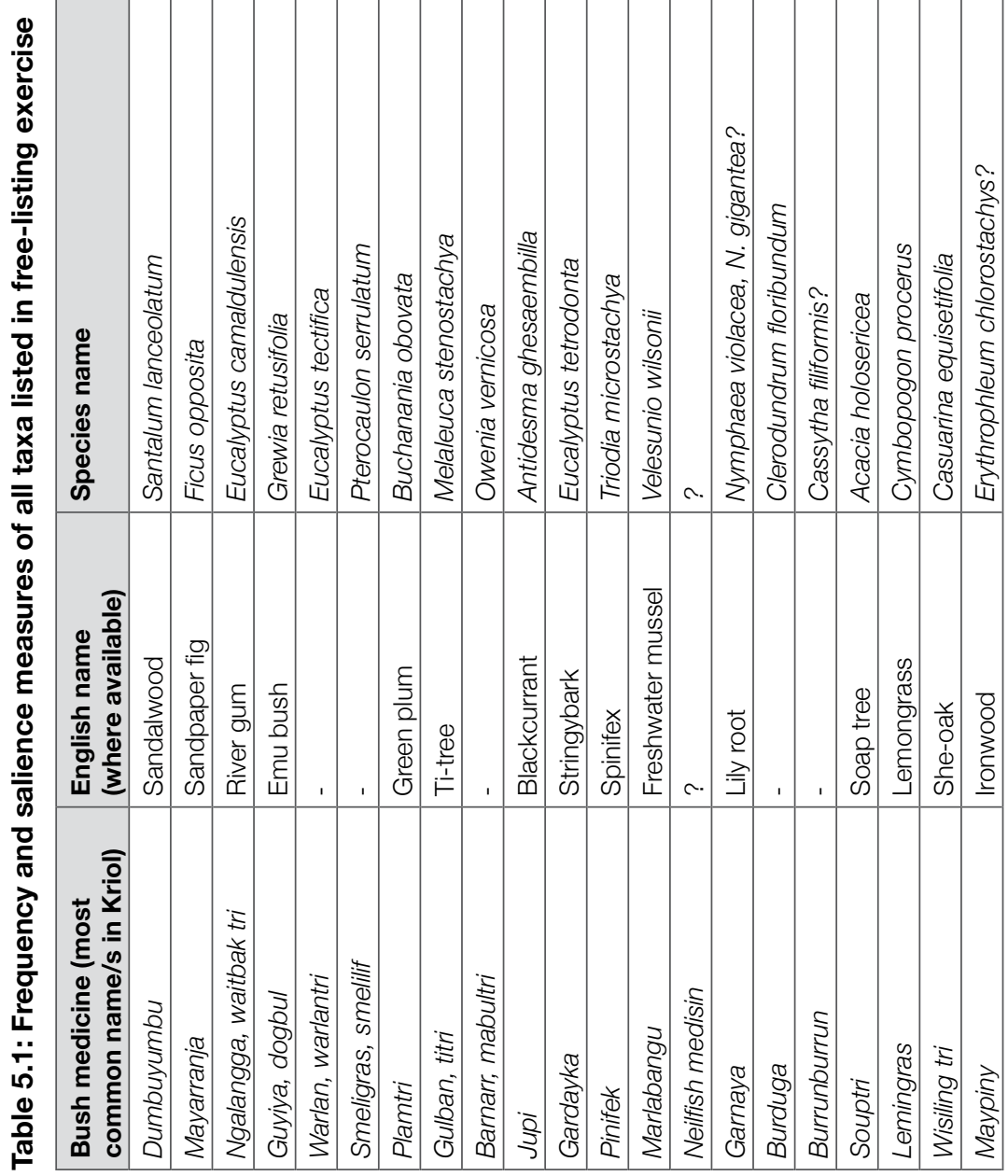


Information derived from recalling the most recent time each participant had used bush medicine provided various data. Information regarding the recency of usage is shown in Table 5.2.

Table 5.2: Most recent instance of using bush medicine: time

\begin{tabular}{|l|c|c|}
\hline Most recent usage & Number of participants $\mathbf{( N = 1 4 )}$ & \% of participants \\
\hline Within a week & 1 & 7 \\
\hline Within a month & 4 & 29 \\
\hline Within six months & 6 & 43 \\
\hline Within a year & 9 & 64 \\
\hline Within three years & 11 & 79 \\
\hline Anytime & 14 & 100 \\
\hline
\end{tabular}

Six different types of bush medicine were used 'most recently', as shown in Table 5.3.

Table 5.3: Most recent instance of using bush medicine: type of medicine used

\begin{tabular}{|l|l|c|}
\hline $\begin{array}{l}\text { Bush medicine type (most } \\
\text { common name/s in Kriol) }\end{array}$ & Scientific name & $\begin{array}{c}\text { Number of participants } \\
\text { (N=14) }\end{array}$ \\
\hline Ngalangga & Eucalyptus camaldulensis & 4 \\
\hline Dumbuyumbu & Santalum lanceolatum & 3 \\
\hline Smeligras/smelilif & Pterocaulon serralatum & 3 \\
\hline Warlan & Eucalyptus tectifica & 2 \\
\hline Maypiny & Erythrophleum chlorastachys & 1 \\
\hline Plamtri & Buchanania obovata & 1 \\
\hline
\end{tabular}

Similarly variable were the ailments or reasons given for the most recent application of bush medicine, as shown in Table 5.4.

Table 5.4: Most recent instance of using bush medicine: ailment treated/ reason for use

\begin{tabular}{|l|c|}
\hline Ailment & Number of participants (N=14) \\
\hline Toothache & 4 \\
\hline Flu/sinus & 3 \\
\hline Sores & 3 \\
\hline Boils & 1 \\
\hline Hangover & 1 \\
\hline Diarrhoea & 1 \\
\hline High blood pressure & 1 \\
\hline Used as a tonic/preventative & 1 \\
\hline
\end{tabular}


When the 14 participants were asked to nominate their top five bush medicines, 12 attempted the task: seven nominated between two and four preferred medicines and five completed a top five list. The results are shown in Table 5.5.

Table 5.5: 'Top 5 bush medicine' survey results

\begin{tabular}{|l|l|c|c|c|c|c|}
\hline \multirow{2}{*}{$\begin{array}{l}\text { Bush medicine type (name/s } \\
\text { given by participants) }\end{array}$} & Scientific name & \multicolumn{5}{|c|}{ Position on 'top 5' list } \\
\hline & & $\mathbf{1}$ & $\mathbf{2}$ & $\mathbf{3}$ & $\mathbf{4}$ & $\mathbf{5}$ \\
\hline Dumbuyumbu & Santalum lanceolatum & 4.5 & 2.5 & 2 & 1 & \\
\hline Warlan & Eucalyptus tectifica & 3 & 1 & & 1 & \\
\hline Ngalangga & Eucalyptus camaldulensis & 1.5 & 2.5 & 2 & 1 & \\
\hline Maypiny & Erythrophleum chlorastachys & 1 & & & & \\
\hline Smeligras/Smelilif & Pterocaulon serralatum & 1 & & & 1 & 2 \\
\hline Plamtri & Buchanania obovate & 1 & & & 1 & 1 \\
\hline Mayarranja & Ficus opposite & & 4 & 1 & & \\
\hline Gulban/Titri & Melaleuca stenostachya & & 1 & 1 & & \\
\hline Guyiya & Grewia retusifolia & & 1 & & & \\
\hline Barnarr/Mabultri & Owenia vernicosa & & & 1 & 1 & \\
\hline Pinifek & Triodia microstachya & & & 1 & & \\
\hline Neilfish medisin & $?$ & & & & 1 & \\
\hline Garnaya & Nymphaea violacea (bulb) & & & & & 1 \\
\hline Gardayka (Stringybark) & Eucalyptus tetrodonta & & & & & 1 \\
\hline
\end{tabular}

\section{Discussion: Gaps and Continuities across Language Shift}

Table 5.1 shows that only one taxon, dumbuyumbu (Santalum lanceolatum), was self-identified by all participants and is clearly the most salient bush medicine. A further three taxa were self-identified by over half the participants and another five taxa were named by four or more. Most of the taxa-12 out of 21 -were self-identified by only one or two participants.

The average number of taxa Kriol-speaking young adults listed in the free-listing task was six: this is low compared to traditional language speaking elders (see e.g. the 14 bush medicine texts in Marra composed by elders Betty and Freda Roberts [2007]). But, collectively, the younger 
group described 21 taxa and, with prompting via a checklist, individuals demonstrated knowledge of up to 13 taxa. This indicates that, while young people's individual taxonomic knowledge of bush medicine is generally lower than that of senior people, collectively they demonstrate a comparable level of knowledge (albeit still diminished). Yet, most taxa that were identified by young people were only known to a few. This may indicate that much of the knowledge that young Kriol speakers collectively hold is fragile and in danger of being lost. Conversely, it may mean that individual knowledge will over time be disseminated to others, leading to some of the currently lesser known taxa increasing their cultural and cognitive salience as the young age. A longitudinal study with the same participants would illuminate this further.

In terms of actual usage, over one-quarter (four of 14) of the participants said they had used bush medicine in the month prior to being interviewed. One male (aged 35) had used ngalangga (Eucalyptus camaldulensis) so recently that he pointed to a just-healed boil on his leg during the interview. In another interview, a female respondent (aged 22) discussing dumbuyumbu (Santalum lanceolatum) casually reported that:

Main mami en dedi bin jis gaji yestadei sambala.

My mum and dad just got some yesterday.

This material, along with other material in this study, contradicts earlier suggestions that bush medicine is practised to a 'limited extent' (Heath $1980,445)$. In addition to the recent use reported by a number of young people, the diverse range of applications they reported further indicates a continuation of complex bush medicine practices. As shown in Table 5.4, eight different reasons or ailments were cited by the 14 participants as to why they had used bush medicine, despite referring only to their most recent usage. The most common treatment was toothache, likely to be attributable to the lack of dental care available in remote regions. Additional reasons for the most recent application of bush medicine included sores, flu/sinus, treating boils, diarrhoea, high blood pressure, hangovers or simply as a tonic or preventative measure. This range of applications is broader than Senior's $(2001,8)$ suggestion that bush medicine was used 'predominantly to treat of colds, flus and headaches', indicating that the knowledge and usage of bush medicine among young people in Ngukurr is more prevalent and sophisticated than previously thought. 
Building upon the evidence that bush medicine has diverse applications, several interviewees revealed prescriptions more sophisticated than single use. One respondent reported treating high blood pressure with a selfadministered two-week course of warlan (Eucalyptus tectifica), with the outcome that it 'kili im olagija' (killed in permanently). Another described a three-day process of treating her youngest son's sores with ngalangga (Eucalyptus camaldulensis):

Ai bin boilimbat ba dis beibiwan las taim. Ngalangga tri. Yea imin sik garra ... daiyariya en ... bedkol plas imin abu det esma du. Aibin jis breigi det ngalangga ba im na en ... breigi from ja gu boili ba im. Neksdei mela bin gu breigi biyain na, det olmen Gumbuli kemp ... neksdei mela bin gu breigi la ... riba.

I boiled it for this baby last time (I used it). Ngalangga tree. Yeah, he was sick with ... diarrhoea and ... sinus, plus he had asthma too. I just broke off some ngalangga for him then and ... broke it off and then went and boiled it for him. The next day we went and broke off some beyond the old man Gumbuli's house ... the next day we went and broke some off at the river.

There are, however, also indications of diminished knowledge and use compared to previous generations. Even after listening to a checklist of bush medicine names, four of the 14 participants could still only identify five or fewer taxa. Likewise, with reported usage, three participants said they had not used bush medicine in three years prior. The taxonomic knowledge displayed by the participants as a cohort resulted in 21 taxa described, yet over half of those taxa were only identified by one or two of the study participants.

For many, bush medicine appears to retain ongoing importance, both as a core component of health belief systems and in its practical application. As social media proliferates in remote communities (that have mobile coverage), bush medicine rates a mention. Facebook status updates (Figures 5.1-5.3) from three adults aged between 25 and 35 show young people are bringing the pre-contact derived domain of bush medicine into new domains that are particular to young people. 


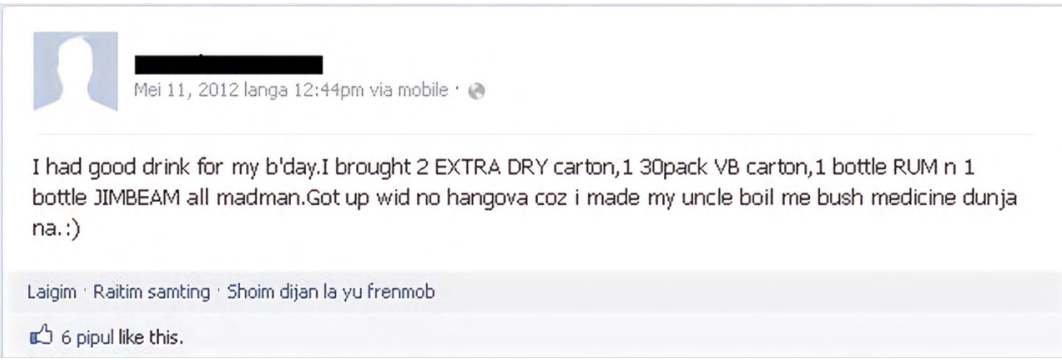

Figure 5.1: Facebook status from a young man in Ngukurr (11 May 2011).

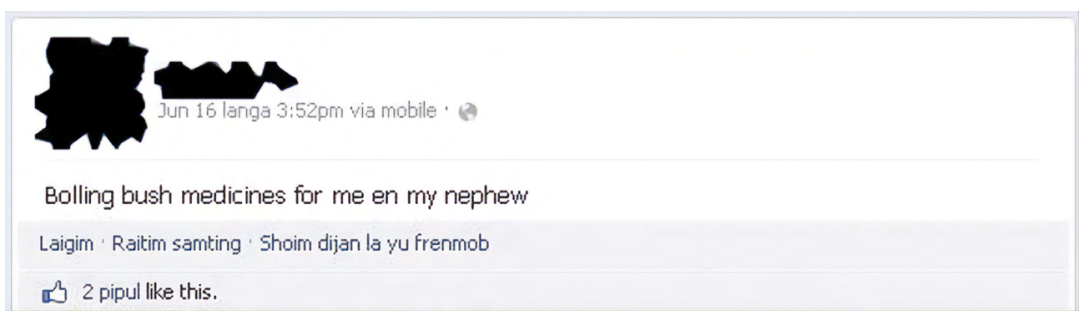

Figure 5.2: Facebook status from a young mother from Minyerri (16 June 2013).

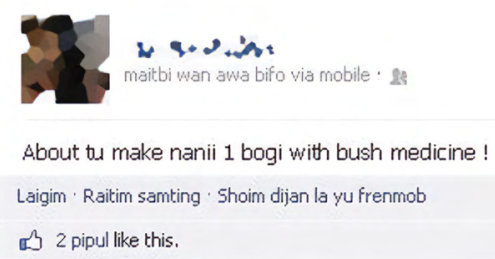

Figure 5.3: Facebook status from a young mother from Ngukurr (16 July 2013).

Evidence of young adults demonstrating innovation in the domain of bush medicine was attested twice during interviews. One participant described mixing medicines to treat an illness-a practice rarely attested in descriptions of Aboriginal bush medicine practice:

(6)

Det taim wen ai bin abu det swainflu, ai bin gu la klinik, en thei bin jis oni gimi penadol. Thei bin jis oni gimi penadol en den, thei bin dalim mi thei kuden du enijing about it. Thei bin dalim mi there's no, any medicine ba det ting, so ai bin lafta yusu det ngalangga na en det ... pinifek gras... en dem, keldapwan na smeligras. Boilim oldot togetha, en bogibogibat na, fo wan wik. 
The time I had swine flu, I went to the clinic, and they only gave me Panadol. They only gave me Panadol, and then, they told me they couldn't do anything about it. They told me there's no medicine for it, so I had to use ngalangga then, and that spinifex grass, and those, curled up things-smelly grass. Boil them all together and then wash with it, for a week.

Another young man reported the use of dumbuyumbu (Santalum lanceolatum) by football players to assist with performance:

Samtaim wi yusu wen wi plei futbul. Bifo wi plei, mela oldot dringgi olda bois, ba meigi lait insaidwei.

Sometimes we use it when we play football. Before we play, we all drink it, all the boys, to make us 'light' on the inside.

\section{Conclusion}

In the 1970s, a Nunggubuyu elder told linguist Jeffrey Heath that bush medicine practices were being abandoned:

Arraga wu-warragurag adanu waari naambuyijimdhang, naambuwarnbang, naambu-warralharrgang, naambu-warramaarndhang anubu-junyung nurri-nyinyung ana-baniyinyjinyung, warramiiiiny-ngambara-wajinyung.

Now it (bush medicine) is no longer in use, we do not use it, we do not do that to it, swallow it, make it. That sort of thing, it is ours, of long ago, of the time of the elders. (Maadi, quoted in Heath 1980,462 , translation has been altered)

Despite assertions such as these-which are generally made more convincing when language shift is an added factor-young people's actual knowledge or use of bush medicine (or lack thereof) has rarely been investigated. The study described in this chapter is possibly the first ethno-botanical study in Australia that focuses specifically on a non-expert group who do not have a traditional language as their first language. Such groups are often perceived by insiders and outsiders alike to a) hold less knowledge and b) engage in bush medicine practices less frequently than older people who are considered experts in such domains and/or are native speakers of an Indigenous language. Previous research in 2003 had argued that Kriol speakers in Ngukurr maintain in their health belief systems a high regard for bush medicine commensurate to that of their 
forebears (Senior 2003). I have found that, while young people generally are less knowledgeable that more senior residents in Ngukurr, they do hold a degree of knowledge about bush medicine and are applying that knowledge to a greater degree than was previously thought. I also might note that Aquino (see Chapter 4, this volume) has made a similar observation with regard to young people's preferences for, and consumption of, native or imported food. The young people who informed this study described and identified over 20 taxa, many described and reported recent instances of usage and application, and a diversity of preferences and practices were revealed. For bush medicine to be mentioned and 'liked' on young people's Facebook feeds and consumed prior to football training indicates that not only are bush medicine practices being maintained in Ngukurr, but also a degree of dynamism is ensuring such practices are riding the waves of rapid cultural change and language shift.

\section{References}

Bordulk, D., M. T. Nikipini Dalak, L. Bennett, R. Tingey, M. Katherine, S. Cutfield, M. Pamkal and G. Wightman. 2012. Dalabon Plants and Animals. Darwin: Department of Land Resource Management.

Farnsworth, N. R. 1966. 'Biological and Phytochemical Screening of Plants'. Journal of Pharmaceutical Sciences 55 (3): 225-76. doi.org/10.1002/jps.2600 550302 .

Heath, J. 1980. Nunggubuyu Myths and Ethnographic Texts. Canberra: Australian Institute of Aboriginal Studies.

Hector, I. K., G. J. Kalabidi, S. Banjo, T. N. N. Dodd, R. J. W. Wavehill, D. Danbayarri, V. N. Wadrill, B. Puntiyarri, I. B. Malyik, B. Wavehill, H. Morris, L. Campbell, F. Meakins and G. Wightman. 2012. Bilinarra, Gurindji and Malngin Plants and Animals. Katherine/Darwin: Department of Land Resource Management.

Hoffman, B. and T. Gallagher. 2007. 'Relative Cultural Importance Indices in Quantitative Ethnobotany'. Ethnobotany Research \& Applications 5: 201-18. doi.org/10.17348/era.5.0.201-218.

Huddleston, G., G. Dinah, B. Roberts and A. George. n.d.-a. Marra Plants and Their Uses, vol. 1. Katherine: Katherine Regional Aboriginal Language Centre.

Huddleston, G., D. Garadji, B. Roberts and A. George. n.d.-b. Marra Plants and Their Uses, vol. 2. Katherine: Katherine Regional Aboriginal Language Centre. 
Huddleston, G., D. Garadji, B. Roberts and A. George. n.d.-c. Marra Plants and Their Uses, vol. 3. Katherine: Katherine Regional Aboriginal Language Centre.

Latz, P. 1995. Bushfires and Bushtucker: Aboriginal Plant Use in Central Australia. Alice Springs, NT: IAD Press.

Levitt, Du. 1981. Plants and People: Aboriginal Uses of Plants on Groote Eylandt. Canberra: Australian Institute of Aboriginal Studies.

McClatchey, W. 2012. 'Basic Methods for Documenting Biological Knowledge Represented in Languages'. In The Oxford Handbook of Linguistic Fieldwork, edited by N. Thieberger, 281-97. Oxford: Oxford University Press.

Merlan, F. 1981. 'Land, Language and Social Identity in Aboriginal Australia'. Mankind 13 (2): 133-48. doi.org/10.1111/j.1835-9310.1981.tb00716.x.

Nganiyurlma Media Association. 1990. Bush Medicine from Ngukurr [Video]. Ngukurr: Nganiyurlma Media Association. 72 mins.

Roberts, B. and F. Roberts. 2007. Bush Medicine Texts. Unpublished manuscript. Ngukurr: Diwurruwurru-Jaru Aboriginal Corporation.

Roberts, J. G., S. Y. Conway, R. Morgan, A. Dirn.gayg, S. Harris, E. Farrar, F. B. Roberts, F. Merlan, E. Collyer, T. Calnan and G. Wightman. 2011. Mangarrayi and Yangman Plants and Animals. Darwin: Department of Land Resource Management.

Scarlett, N., N. White and J. Reid. 1982. 'Bush Medicines: The Pharmacopoeia of the Yolngu of Arnhem Land'. In Body, Land and Spirit: Health and Healing in Aboriginal Society, edited by J. Reid, 154-91. St Lucia, Queensland: University of Queensland Press.

Senior, K. 2001. Health Beliefs and Behaviour: The Opportunities And Practicalities Of 'Looking After Yourself' in Ngukurr. Wollongong, NSW: South East Arnhem Land Collaborative Research Project, University of Wollongong.

Senior, K. 2003. 'A Gudbala Laif ? Health and Wellbeing in a Remote Aboriginal Community-What Are the Problems and Where Lies Responsibility?' PhD thesis, The Australian National University, Canberra.

Winydjorrodj, P., S. Flora, N. Brown, P, Jatbula, J. Galmur, F. Merlan and G. Wightman. 2005. Jawoyn Plants and Animals. Darwin: Northern Territory Department of Natural Resources, Environment and the Arts. 
This text is taken from Indigenous Australian Youth Futures: Living the Social Determinants of Health, edited by Kate Senior, Richard Chenhall and Victoria Burbank, published 2021 by ANU Press, The Australian National University, Canberra, Australia.

doi.org/10.22459/IAYF.2021.05 